\section{JURNAL ABDIMAS

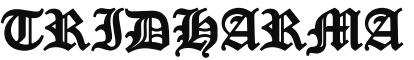 \\ AtA:}

P-ISSN 2615-6849, E-ISSN 2622-3686

Jurnal ABDIMAS Vol. 2, No. 2, April 2021,Hal (125-129)

@Prodi Manajemen Fakultas Ekonomi Universitas Pamulang

Email: abdimasjurnal.unpam@gmail.com Telp: (021) 741-2566

\title{
BIMBINGAN TEKNIS PEMBUATAN PERATURAN DESA DI DESA KAWUNGLARANG, KECAMATAN RANCAH, KABUPATEN CIAMIS
}

\author{
Yoyon M. Darusman ${ }^{1}$, Susanto $^{2}$, Bambang Wiyono ${ }^{3}$, Muhamad Iqbal ${ }^{4}$ dan Bastianon $^{5}$ \\ 1,2,3,5 Dosen Magister Hukum Universitas Pamulang ${ }^{4}$ Dosen Ilmu Hukum S1 Universitas \\ Pamulang \\ EMAIL : yoyon.darusman@yahoo.co.id
}

Universitas Pamulang

yoyon.darusman@yahoo.co.id susanto@unpam.ac.id

\begin{abstract}
The Village Regulation is stipulated by the Village Head after being discussed and agreed upon with the Village Consultative Body which is a legal and policy framework in the administration of Village Government and Village Development. The stipulation of Village Regulations is a description of the various powers that the Village has with reference to the provisions of higher laws and regulations. So that as a legal product, the Village Regulation must not conflict with higher regulations and may not harm the public interest. One of the reasons for the promulgation of Law Number 6 of 2014 concerning Villages is the recognition that villages have rights of origin and traditional rights in regulating and managing the interests of the local community and playing a role in realizing the ideals of independence based on the 1945 Constitution of the Republic of Indonesia. This is because the recognition of the village as an autonomous region makes the village have a major role in managing, empowering and advancing the available resources, both natural and human resources. So that in the end they are able to move the wheels of development which must be accompanied by an awareness of the understanding of the spirit of autonomy for all village residents and the capacity of the apparatus as well as the community in understanding governance. Village I Traditional Village Institutions, namely Village / Traditional Village Government institutions consisting of Village / Traditional Village Governments and Village / Traditional Village Consultative Bodies, Village Community Institutions, and traditional institutions. The Village I Traditional Village Head or what is referred to by any other name is the head of the Village I Traditional Village Administration who leads the administration of the Village Government. The Village / Traditional Village Head or what is referred to by any other name has an important role in his position as an extension of the state close to the community and as a community leader. Tri Dharma Perguruan Tinggi is the vision of all tertiary institutions in Indonesia which consists of education and teaching, research and development, and community service. As an effort to realize this vision, the Pamulang University Master of Law study program by involving lecturers and students has held Community Service in the form of providing technical guidance to village heads and the Kawunglarang Village Consultative Body, Rancah District in drafting village regulations to be carried out in Kawunglarang village, Rancah District, Ciamis Regency.
\end{abstract}

\section{Keywords: Technical Guidance, Village Regulations}

\section{Abstrak}

Peraturan Desa ditetapkan oleh Kepala Desa setelah dibahas dan disepakati bersama Badan Permusyawaratan Desa merupakan kerangka hukum dan kebijakan dalam penyelenggaraan Pemerintahan Desa dan Pembangunan Desa. Penetapan Peraturan Desa merupakan penjabaran atas berbagai kewenangan yang dimiliki Desa mengacu pada ketentuan peraturan perundangundangan yang lebih tinggi. Sehingga sebagai sebuah produk hukum, Peraturan Desa tidak boleh bertentangan dengan peraturan yang lebih tinggi dan tidak boleh merugikan kepentingan umum. Salah satu daru alasan di buatnya Undang-undang Nomor 6 Tahun 2014 tentang Desa 
adalah pengakuan bahwa Desa memiliki hak asal usul dan hak tradisional dalam mengatur dan mengurus kepentingan masyarakat setempat dan berperan mewujudkan cita-cita kemerdekaan berdasarkan Undang-Undang Dasar Negara Republik Indonesia Tahun 1945 Hal ini disebabkan karena dengan diakuinya desa sebagai sebuah daerah otonom menjadikan desa memiliki peran utama dalam mengelola, memberdayakan dan memajukan sumber daya yang tersedia, baik sumber daya alam maupun sumber daya manusia. Sehingga pada akhirnya mampu menggerakkan roda pembangunan yang harus diiringi kesadaran akan pemahaman spirit otonomi bagi seluruh penggerak warga desa dan kapasitas perangkat juga masyarakat dalam memahami tata kelola pemerintahan. Kelembagaan Desa/Desa Adat, yaitu lembaga Pemerintahan Desa/Desa Adat yang terdiri atas Pemerintah Desa/Desa Adat dan Badan Permusyawaratan Desa/Desa Adat, Lembaga Kemasyarakatan Desa, dan lembaga adat. Kepala Desa/Desa Adat atau yang disebut dengan nama lain merupakan kepala Pemerintahan Desa/Desa Adat yang memimpin penyelenggaraan Pemerintahan Desa. Kepala Desa/Desa Adat atau yang disebut dengan nama lain mempunyai peran penting dalam kedudukannya sebagai kepanjangan tangan negara yang dekat dengan masyarakat dan sebagai pemimpin masyarakat. Tri Dharma Perguruan Tinggi merupakan visi dari seluruh perguruan tinggi di Indonesia yang terdiri dari pendidikan dan pengajaran, penelitian dan pengembangan, serta pengabdian kepada masyarakat. Sebagai upaya untuk mewujudkan visi tersebut, Program studi Magister Hukum Universitas Pamulang dengan melibatkan Dosen dan para Mahasiswa telah mengadakan Pengabdian Masyarakat dalam bentuk memberikan Bimbingan teknis kepada kepala desa dan Badan Permusyawaratan Desa Kawunglarang, Kecamatan Rancah dalam penyusunan Peraturan desa yang akan dilakukan di desa Kawunglarang, Kecamatan Rancah, Kabupaten Ciamis.

Kata Kunci: Bimbingan Teknis, Peraturan Desa

\section{PENDAHULUAN}

Salah satu daru alasan di buatnya Undang-undang Nomor 6 Tahun 2014 tentang Desa adalah pengakuan bahwa Desa memiliki hak asal usul dan hak tradisional dalam mengatur dan mengurus kepentingan masyarakat setempat dan berperan mewujudkan cita-cita kemerdekaan berdasarkan Undang-Undang Dasar Negara Republik Indonesia Tahun 1945, Hal ini disebabkan karena dengan diakuinya desa sebagai sebuah daerah otonom menjadikan desa memiliki peran utama dalam mengelola, memberdayakan dan memajukan sumber daya yang tersedia, baik sumber daya alam maupun sumber daya manusia. Sehingga pada akhirnya mampu menggerakkan roda pembangunan yang harus diiringi kesadaran akan pemahaman spirit otonomi bagi seluruh penggerak warga desa dan kapasitas perangkat juga masyarakat dalam memahami tata kelola pemerintahan.

Kelembagaan Desa/Desa Adat, yaitu lembaga Pemerintahan Desa/Desa Adat yang terdiri atas Pemerintah Desa/Desa Adat dan Badan Permusyawaratan Desa/Desa Adat, Lembaga Kemasyarakatan Desa, dan lembaga adat.
Kepala Desa/Desa Adat atau yang disebut dengan nama lain merupakan kepala Pemerintahan Desa/Desa Adat yang memimpin penyelenggaraan Pemerintahan Desa.

Kepala Desa/Desa Adat atau yang disebut dengan nama lain mempunyai peran penting dalam kedudukannya sebagai kepanjangan tangan negara yang dekat dengan masyarakat dan sebagai pemimpin masyarakat. Mengingat kedudukan, kewenangan, dan Keuangan Desa yang semakin kuat, penyelenggaraan Pemerintahan Desa diharapkan lebih akuntabel yang didukung dengan sistem pengawasan dan keseimbangan antara Pemerintah Desa dan lembaga Desa. Lembaga Desa, khususnya Badan Permusyawaratan Desa yang dalam kedudukannya mempunyai fungsi penting dalam menyiapkan kebijakan Pemerintahan Desa bersama Kepala Desa, harus mempunyai visi dan misi yang sama dengan Kepala Desa sehingga Badan Permusyawaratan Desa tidak dapat menjatuhkan Kepala Desa yang dipilih secara demokratis oleh masyarakat Desa Badan. Permusyawaratan Desa merupakan badan permusyawaratan di tingkat Desa 
JURNAL ABDIMAS

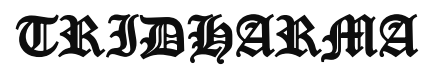

AlA:
P-ISSN 2615-6849, E-ISSN 2622-3686

Jurnal ABDIMAS Vol. 2, No. 2, April 2021,Hal (125-129)

@ Prodi Manajemen Fakultas Ekonomi Universitas Pamulang

Email: abdimasjurnal.unpam@gmail.com Telp: (021) 741-2566 yang turut membahas dan menyepakati berbagai kebijakan dalam penyelenggaraan Pemerintahan Desa. Dalam upaya meningkatkan kinerja kelembagaan di tingkat Desa, memperkuat kebersamaan, serta meningkatkan partisipasi dan pemberdayaan masyarakat, Pemerintah Desa dan/atau Badan Permusyawaratan Desa memfasilitasi penyelenggaraan Musyawarah Desa.

Berdasarkan permasalahan diatas, maka Tim PKM dari Magister Hukum Universitas Pamulang dengan jumlah 5 dosen bersama 5 mahasiswa mengadakan bimbingan teknis dengan tema "BIMBINGAN TEKNIS PEMBUATAN PERATURAN DESA DI DESA KAWUNGLARANG, KECAMATAN RANCAH, KABUPATEN CIAMIS".

Tujuan dari kegiatan ini adalah memberi pengenalan penyusunan peraturan desa. Kegiatan ini sangat bermanfaat bagi desa khususnya mengenai pembentukan peraturan desa.

\section{METODE PELAKSANAAN KEGIATAN}

Pada tahapan Koordinasi dan Perencanaan, team PKM melakukan peninjauan lokasi dan koordinasi dengan Kepala Desa Kawunglarang mengenai akan dilaksanakan PKM. Setelah tahapan koordinasi selanjutnya adalah tahapan pelaksanaan, dimana pelaksanaan kegiatan ini dilakukan di Balai Desa Kawunglarang yang dihadiri oleh Kepala Desa, Aparat Desa, Badan Permusyawaratan Desa, Ketua RT dan RW, Ibu-ibu penggerak PKK dan muda-mudi.

Kegiatan ini dilaksanakan tanggal 01 April 2021 sampai dengan 03 April 2021. Tahapan terakhir adalah melakukan monitoring dan evaluasi pelaksanaan PKM. Dimana diketahui hasil monitoring dan evaluasi terhadap peserta PKM diperoleh data bahwa peserta PKM sudah terbantu dan memahami mengenai pemaparan PKM.

\section{HASIL DAN PEMBAHASAN}

Kegiatan Pengabdian Kepada Masyarakat (PKM) yang dilaksanakan pada tanggal 01 April 2021 sampai dengan
03 April 2021 telah berjalan dengan baik dan lancar. Sebelum tanggal tersebut juga dilakukan komunikasi secara intens sebagai analisis awal. Kegiatan ini diikuti Kepala Desa, Aparat Desa, Badan Permusyawaratan Desa, Ketua RT dan RW, Ibu-ibu penggerak PKK dan mudamudi dari Desa Kawunglarang, Kecamatan Rancah, Kabupaten Ciamis, Jawa Barat.

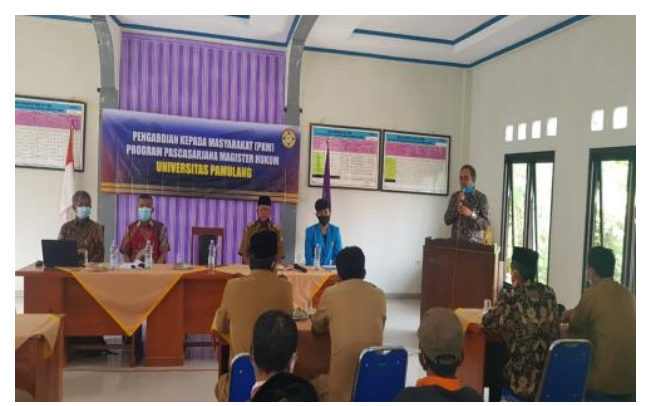

Gambar 1 : Penyampaian Materi Oleh Dr. Yoyon M. Darusman, SH, MM

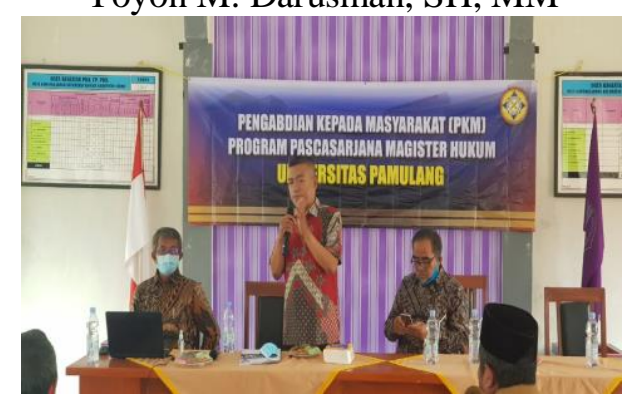

Gambar 2 : Penyampaian Materi Oleh Dr. Susanto, SH, MM, MH

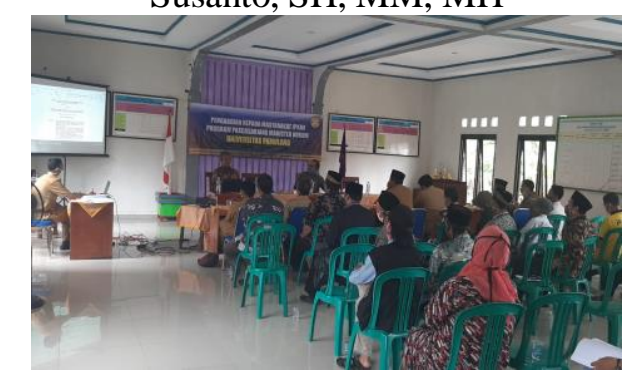

Gambar 3 : Penyampaian Materi Oleh Dr. Bambang Wiyono, $\mathrm{SH}, \mathrm{MH}$

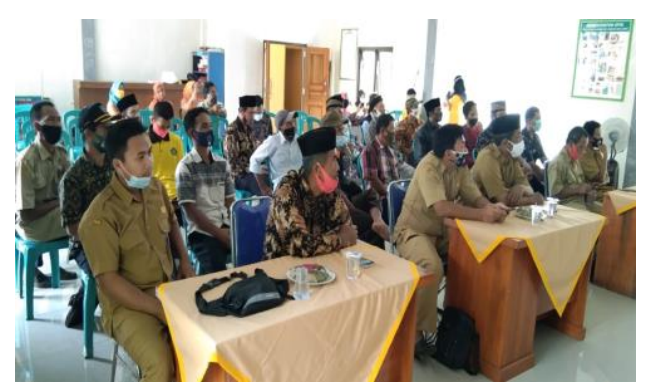

Gambar 4 : Antusiasme Peserta PKM 
Disampaikan oleh pemateri PKM bahwa Kelahiran Undang-Undang Nomor 6 Tahun 2014 tentang Desa membawa perubahan yang signifikan bagi eksistensi desa.Salah satunya adalah kemandirian desa yang lebih kuat, baik dari segi politik, ekonomi, sosial dan budaya.Undangundang desa. Selain itu, desa juga dituntut berperan aktif dalam mewujudkan citacita kemerdekaan sebagaimana tertuang dalam Pembukaan UndangUndang Dasar Negara Republik Indonesia Tahun 1945. Pasal 1 UndangUndang Nomor 6 Tahun 2014 tentang Desa menyatakanbahwa Pemerintahan Desa adalah "penyelenggaraan urusan pemerintahan dan kepentingan masyarakat setempat dalam sistem pemerintahan Negara Kesatuan Republik Indonesia".

Pasal tersebut menunjukkan bahwa Pemerintah Desa memiliki dua tugas pokok, yaitu sebagai penyelenggara urusan pemerintahan dan penyelenggara kepentingan masyarakat. Siapakah pemerintah desa itu? Dalam Pasal 1 dan Pasal 25 UndangUndang ini juga dinyatakan bahwa yang dimaksud dengan Pemerintah Desa adalah Kepala Desa atau yang disebut dengan nama lain, dibantu dengan perangkat desa.

Dalam tata kelola pemerintahan desa, Perdes menjadi sangat krusial karena menjadi dasar hukum bagi pelaksanaan berbagai program dan kegiatan desa. Penjelasan tentang tugas dan wewenang Kepala Desa dan anggota BPD di atas menunjukkan bahwa wewenang penetapan Peraturan Desa ada di Kepala Desa.Tetapi penetapan tersebut hanya bisa dilakukan setelah Rancangan Perdes dibahas dan disepakati bersama BPD (Pasal 69 [3]) Bimbingan teknis Penyusunan Peraturan desa ini akan lidakukan secara langsung/tatap muka dengan seluruh kepala desa dan Badan Permusyawaratan Desa dengan melibatkan Dosen dan Mahasiswa Program Studi Pasca Sarjana Universitas Pamulang, Pelatihan/Bimbingan Teknis (Bimtek) adalah suatu kegiatan dimana para peserta diberi pelatihanpelatihan yang bermanfaat dalam meningkatkan kompetensi peserta yang dimana materi yang diberikan meliputi Membangun Tim
Kerja Efektif, Teknik Komunikasi dalam Konteks Pelayanan Prima, Survey Indeks Kepuasan Masyarakat dan Penanganan Keluhan Pelanggan, Tata Pemerintahan yang Baik dan Profesionalisme Aparatur, Kepemimpinan, dll.

Dalam rangka meningkatkan kemampuan Kepala Desa dan Badan Permusyawaratan Desa tersebut dan untuk melaksanakan salah satu Visi Universitas Pamulang khususnya Program studi Magister Hukum akan melaksanakan Pengabdian Masyarakat berupa memberikan Bimbingan teknis dalam penyusunan Peraturan desa. Sebagai sebuah produk hukum, Peraturan Desa tidak boleh bertentangan dengan peraturan yang lebih tinggi dan tidak boleh merugikan kepentingan umum, yaitu: a. terganggunya kerukunan antarwarga masyarakat; b. terganggunya akses terhadap pelayanan publik; c. terganggunya ketenteraman dan ketertiban umum; $d$. terganggunya kegiatan ekonomi untuk meningkatkan kesejahteraan masyarakat Desa; dan e. diskriminasi terhadap suku, agama dan kepercayaan, ras, antargolongan, serta gender. Sebagai sebuah produk politik,

Hal itu dimaksudkan agar pelaksanaan Peraturan Desa senantiasa dapat diawasi secara berkelanjutan oleh warga masyarakat Desa setempat mengingat Peraturan Desa ditetapkan untuk kepentingan masyarakat Desa. Apabila terjadi pelanggaran terhadap pelaksanaan Peraturan Desa yang telah ditetapkan, Badan Permusyawaratan Desa berkewajiban mengingatkan dan menindaklanjuti pelanggaran dimaksud sesuai dengan kewenangan yang dimiliki. Itulah salah satu fungsi pengawasan yang dimiliki oleh Badan Permusyawaratan Desa.

\section{SIMPULAN}

Berdasarkan hasil kegiatan PKM pada pada Desa Kawunglarang, Kecamatan Rancah, Kabupaten Ciamis, Jawa Barat dengan metode bimbingan teknis menunjukkan bahwa :

1. Secara umum pada awalnya baik Kepala Desa, BPD, Ketua RT/RW, Ibu-ibu penggerak PHK serta muda 
JURNAL ABDIMAS

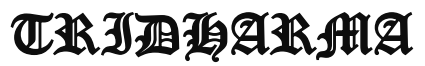

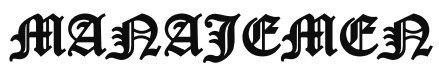

P-ISSN 2615-6849, E-ISSN 2622-3686

Jurnal ABDIMAS Vol. 2, No. 2, April 2021,Hal (125-129)

@ Prodi Manajemen Fakultas Ekonomi Universitas Pamulang

Email: abdimasjurnal.unpam@ gmail.com Telp: (021) 741-2566 mudi desa belum begitu memahami mengenai urgensi Peraturan Desa dan bagaimana pembuatan peraturan desa yang baik dan sesuai dengan ketentuan perundang-undangan.

2. Kepala Desa mengalami beberapa permasalahan mengenai hutan desa.

\section{DAFTAR PUSTAKA}

Arofa, E., Bachtiar, B., Susanto, S., Santoso, B., \& Wiyono, B. (2021). Bimbingan Teknis Pembuatan Peraturan Desa. Pro Bono Jurnal Pengabdian Kepada Masyarakat, 1(01).

Darusman, Y. M., Susanto, S., Anggraeni, R. D., Bachtiar, B., \& Bastinaon, B. (2020). Sosialisasi Undang-Undang Perlindungan Anak Dan Kdrt Kelurahan Pulau Panggang Kabupaten Kepulauan Seribu. Jurnal Lokabmas Kreatif, 1(1), 76-82.

Darusman, Y. M., Susanto, S., Anggraeni, R. D., Bachtiar, B., \& Bastinaon, B. (2020). Sosialisasi Undang-Undang Perlindungan Anak Dan Kdrt Kelurahan Pulau Panggang Kabupaten Kepulauan Seribu. Jurnal Lokabmas Kreatif, 1(1), 76-82.

Darusman, Y. M., Susanto, S., Anggraeni, R. D., Gueci, R. S., \& Yanto, O. (2019). Penyuluhan Peraturan Perundang-Undangan Pemilihan Umum (Pemilu) Tahun 2019 (Studi Kasus Pada Politeknik Ilmu Pemasyarakatan (Poltekip) Kementerian Hukum Dan Ham Ri, Depok, Jawa Barat). Jurnal Abdi Masyarakat Humanis, 1(1).

Susanto, M. I. (2019). Kedudukan Hukum People Power Dan Relevansinya Dengan Hak Kebebasan Berpendapat Di Indonesia. Volksgeist: Jurnal Ilmu Hukum Dan Konstitusi, 2(2), 225-237.

Susanto, S., Wiyono, B., Darusman, Y. M., \& Bastianon, B. (2021). Bimbingan Teknis Pembuatan Peraturan Desa (Desa Hajosari Lor, Kecamatan Adiwerna, Kabupaten Tegal). Pro Bono Jurnal Pengabdian Kepada Masyarakat, 1(01).
Wiyono, B., Arofa, E., Wulansari, E. M., \& Susanto, S. (2020). Sosialisasi Undang-Undang Kdrt Dan Perlindungan Anak. Jurnal Abdimas Tri Dharma Manajemen, 1(3), 42-47

Yanto, O., Susanto, S., Darusman, Y. M., Wiyono, B., \& Gueci, R. S. (2020). Sosialisasi Dan Pelatihan E-Litigasi Di Lembaga Bantuan Hukum Unggul Tangerang Selatan Guna Meningkatkan Profesinalisme Dalam Rangka Pendampingan Masyarakat Pencari Keadilan Melalui Aplikasi Komputer. Jurnal Abdimas Tri Dharma Manajemen, 1(2).

Yanto, O., Susanto, S., Nugroho, A., Santoso, B., \& Gueci, R. S. (2020). Sosialisasi Kekayaan Intelektual Guna Menumbuhkembangkan Usaha Dalam Rangka Menghadapi Persaingan Global Pada Revolusi 4.0. Abdi Laksana, 1(2).

Yanto, O., Susanto, S., Wiyono, B., \& Bastianon, B. (2021). Bimbingan Teknis Pembuatan Peraturan Desa Di Desa Pagedangan, Kecamatan Adiwerna, Kabupaten Tegal, Jawa Tengah. Pro Bono Jurnal Pengabdian Kepada Masyarakat, 1(01). 